\title{
Bioconversion of Selected Solid Wastes by Control Cultivation of Oyster Mushroom, Pleurotus florida and its Nutrient Analysis
}

\author{
Oinam Jennifer ${ }^{1 *}$, Laishram Joymati Devi ${ }^{2}$ \\ ${ }^{1}$ Research Scholar, Department of Zoology, CMJ University, Jorabad, India \\ ${ }^{2}$ Associate Professor, Department of Zoology, DM College of Science, Imphal, India \\ *Corresponding author: jennifertaree@gmail.com
}

\begin{abstract}
Mushrooms are a source of nutrition particularly in respect of proteins and vitamins. It has been rightly called "vegetable meat". Apart from being potential protein and energy source, mushrooms are famous for their medicinal values. In addition to their fascination for the gourmet, they are nature's most active agents in the disposal of forest's waste materials. Not only in disposing timber, but also helps in converting dead plants into available food. They are efficient agents, fitting into the nutrient cycle of farms and forests. As they utilize agricultural by products and wastes as their substrate, mushroom cultivation is an eco-friendly activity. In a country like India where vegeterians dominate, every attempt should be made to popularize a vegetable protein source like mushroom. A study on the cultivation of oyster mushroom, Pleurotus florida was undertaken. It was found to grow on various solid wastes viz. paddy straw, rice husk, saw dust, water hyacinth and a mixture of all the selected substrates. The oyster mushroom cultivated on the paddy straw gives the maximum yield with high content of protein, carbohydrate and lipid.
\end{abstract}

Keywords: Eco-friendly, Pleurotus florida, Nutritional contents.

\section{Introduction}

According to Chang (1991), "the mushroom is a macrofungus with distinctive fruiting body which can be either epigeous or hypogeous and large enough to be seen with naked eye and to be picked by hand." Mushroom farms may be use as disposal sites for agricultural waste products. Mushrooms are found to possess the two basic abilities of biodegradation and bioaccumulation for the bioremediation of wastes. Mushroom cultivation serves as the most efficient and economically viable biotechnology for the conversion of long cellulose waste materials into high quality protein food (Dike et.al., 2011). The protein- extracting ability of oyster mushrooms makes them a very popular alternative energy source for dieting individuals (Shah, 2004). Mushrooms are able to convert substrate mass into edible mushroom biomass often exceeding $100 \%$ biological efficiency.

A study on the cultivation of Pleurotus florida was undertaken. It was cultivated on five selected solid wastes viz. Paddy straw, Rice husks, water hyacinth, Saw dust and a mixture of all the selected four substrates. The cultivation was carried out in polythene bags (containing 500gm paddy straw on dry weight basis per bag) using grain spawn as well as the nutritional contents like the protein, lipid and carbohydrate were estimated.

\section{Materials and Method}

Cultivation of the species, Pleurotus florida

Materials:

1. Mushroom Spawn

2. Paddy straw, rice husks, water hyacinth and saw dust for making bed substrates $: 500 \mathrm{gm} / \mathrm{bag}$.

3. Perforated transparent polythene bags: $30 \mathrm{x} 40 \mathrm{~cm}$

4. Spawn:100gms/bag

5. Sprayer: 1 litre capacity

6. Containers for sterilization.

7. Binding threads.

A. Methodology

1) Spawn preparation

The primary innoculum was prepared from the fresh fruiting body of the mushroom through tissue culture method and was maintained and multiplied by sub culturing on sterilized PDA medium in petri dishes and test tubes. The spawn was prepared on coarse paddy grains. The grains were half boiled and filled in transparent polythene bags, which were then sterilized in an autoclave at $15 \mathrm{psi}$ for 30 minutes. The inoculation was made on the following day under aseptic conditions and incubated at room temperature till the grains were covered with white mycelial growth.

2) Substrate preparation

Pleurotus florida was grown on the selected substrates viz. paddy straw, rice husks, water hyacinth, saw dust and mixture of the four selected substrates. The substrate paddy straw was obtained from a nearby farmland, rice husk from a rice mill, saw dust from a saw mill and water hyacinth from a nearby pond.

\section{3) Soaking}

The substrates were chopped into $6-8 \mathrm{~cm}$ pieces and soaked in fresh water separately for a minimum of 20 hours and a 
maximum of an overnight.

4) Sterilization and spawning

The substrates were boiled for at least 30 minutes and were let to cool down at room temperature and the excess water was strained. The substrates were then filled in the perforated polythene bags layer by layer sandwiching the spawn grain respectively. The open ends were then bound by the binding threads and kept at a temperature maintained at about $300 \mathrm{C}$ and well protected from pests.

5) Cropping and harvest

After the spawn run has completed and the bags were fully impregnated with white mycelia, the polythene bags were removed carefully. The open blocks were kept on racks about $20 \mathrm{~cm}$ apart. Water was sprayed regularly to keep it moist. Within 3-4 days of the spawn run pin-heads were seen and within another 3-4 days' mushrooms were ready for harvest.

\section{Analysis for Nutritional Contents of the Mushroom Harvested}

The mushroom harvested from the various substrates were analysed for the following,

1) Protein content (Lowry et.al., 1951)

The protein content of the mushroom was estimated by the method described by Lowry et.al., (1951)

2) Carbohydrate content (Hedge and Hofreiter,1962)

The carbohydrate content of the mushroom was estimated by the method described by Hedge and Hofreiter, (1962)

3) Total Lipid content (Folch,1954)

The total lipid content of the mushroom was estimated by using the method described by Folch, 1954 .

4) Biological efficiency

The biological efficiency was calculated as a percentage of the yield of the fresh mushroom to the dry weight of the substrates.

\section{Results}

Table 1

Sporophore initiation period and first (in days) of Pleurotus florida

\begin{tabular}{|c|l|c|c|}
\hline S.no. & Substrates & $\begin{array}{c}\text { Sporophore initiation } \\
\text { (in days) }\end{array}$ & $\begin{array}{c}\text { First flush } \\
\text { (in days) }\end{array}$ \\
\hline 1. & Paddy straw & 16 & 21 \\
2. & Water hyacinth & 21 & 28 \\
3. & Rice Husk & 18 & 21 \\
4. & Saw dust & 23 & 30 \\
5. & Mixed substrate & 20 & 25 \\
\hline
\end{tabular}

Different substrates showed different period (in days) for sporophore initiation. A minimum period of 16 days was taken by paddy straw for sporophore initiation followed by rice husk (18 days), mixed subsrate (20 days), water hyacinth (21days) and a maximum period of 23 days was recorded in saw dust substrate.

Regarding the first flush, paddy straw and rice husk gave first flush in a minimum of 21 days followed by mixed substrate in 25 days, water hyacinth in 28 days and a maximum of 30 days by the saw dust substrate.
Table 2

Total yield (in grams) of P.florida on different substrates in total number of days

\begin{tabular}{|c|l|l|l|}
\hline S.no. & Substrates & Total number of days taken & $\begin{array}{l}\text { Total yield* } \\
\text { (gm/500gm) }\end{array}$ \\
\hline 1. & Paddy straw & 42 & 398.78 \\
2. & Water hyacinth & 54 & 256.41 \\
3. & Rice Husk & 60 & 281.81 \\
4. & Saw dust & 66 & 170.62 \\
5. & Mixed substrate & 49 & 284.84 \\
\hline
\end{tabular}

*Mean of replicates

The order of efficiency of total production in 500 gms substrate is,

paddy straw $(398.78 \mathrm{gms} / 500 \mathrm{gms})>$ mixed substrate $(284.83 \mathrm{gms})>$ rice husk $(281.81 \mathrm{gms})>$ water hyacinth (256.41gms) >saw dust (170.62gms).

Table 3

Yield and biological efficiency of P.florida grown on different substrates

\begin{tabular}{|c|l|l|l|}
\hline S.no. & Substrates & $\begin{array}{l}\text { Total yield* } \\
\text { (gm/500gm) }\end{array}$ & Biological efficiency(\%) \\
\hline 1. & Paddy straw & 398.78 & 79.75 \\
2. & Water hyacinth & 256.41 & 64.10 \\
3. & Rice Husk & 281.81 & 56.36 \\
4. & Saw dust & 170.62 & 34.12 \\
5. & Mixed substrate & 284.84 & 71.21 \\
\hline
\end{tabular}

The order of biological efficiency is paddy straw $(79.75 \%)$ $>$ mixed substrate $(71.21 \%)>$ water hyacinth $(64.10 \%)>$ rice husk (56.36\%) >saw dust (34.12\%).

Table 4

Protein, Carbohydrate and lipid profile of P.florida cultivated on different substrates

\begin{tabular}{|l|l|l|l|l|l|}
\hline S.no. & Substrates & $\begin{array}{c}\text { Protein } \\
(\boldsymbol{\%})\end{array}$ & $\begin{array}{c}\text { Carbohydrate } \\
(\boldsymbol{\%})\end{array}$ & $\begin{array}{c}\text { Lipid } \\
(\boldsymbol{\%})\end{array}$ & $\begin{array}{c}\text { Caloric } \\
\text { value (cal) }\end{array}$ \\
\hline 1. & Paddy straw & 26.2 & 10.68 & 0.3 & 194.67 \\
2. & Water & 22.5 & 7.69 & 0.3 & 161.47 \\
3. & hyacinth & 25.0 & 8.82 & 0.1 & 178.35 \\
4. & Rice husk & 20.0 & 9.97 & 0.2 & 155.76 \\
5. & Saw dust & 25.0 & 8.95 & 0.1 & 178.97 \\
& Mixed & & & & \\
& substrate & & & & \\
\hline
\end{tabular}

The order of protein (\%) of P.florida grown on different substrates is paddy straw $(26.2 \%)>$ rice husk $(25.0 \%)=$ Mixed substrate $(25.0 \%)>$ water hyacinth $(22.5 \%)>$ saw dust $(20.0 \%)$.

The order of carbohydrate content (\%) of P.florida grown on different substrates is paddy $\operatorname{straw}(26.2 \%)>\operatorname{saw} \operatorname{dust}(9.97 \%)>$ mixed substrate $(8.95 \%)>$ rice husk $(8.82 \%)>$ water hyacinth $(7.69 \%)$

The order based on lipid content of P.florida grown on different substrates is paddy $\operatorname{straw}(0.3 \%)=$ water hyacinth $(0.3 \%)>$ saw dust $(0.2 \%)>\operatorname{rice}$ husk $(0.1 \%)=$ mixed substrate $(0.1 \%)$.

The order based on the caloric value (cal) is paddy straw $(194.67)>$ mixed substrate $(178.97)>$ rice husk $(178.35)>$ water hyacinth (161.47) > saw dust (155.76). 


\section{Discussion}

India being an agricultural country, agricultural wastes such as paddy straw and rice husk are available abundantly which if not properly used will pollute the environment. Water hyacinth is also considered to be menace to the aquatic environment as well as in navigation. This wastes can be successfully utilized for mushroom cultivation and it a way of solid wastes management too.

Suitability of paddy straw as bed substrates for oyster mushroom cultivation was reported by Bano and Srivastav (1962) and Block et.al (1958). Zadrazil and Schneidereit (1972) too observed that rice husk can be successfully for the oyster mushroom cultivation. Pani and Mohanty (1998) also reported water hyacinth to be a suitable substrate for oyster mushroom cultivation. Sharma and Jandaik (1981) reported the use of mixed substrates as bedding material with the view that mixed substrate provide a more balanced supply of nutrients to the mushroom. These findings were found to be similar with the present work. Besides, other agro wastes such as saw dust, rice husk, maize cobs, coir pith etc., which are mostly burnt leading to waste of energy pollution of the environment, can be converted into food, feed and fuel by oyster mushroom cultivation, representing the only economically profitable biotechnological process for the bioconversion of wastes plants residues.

In the present study quick sporophore initiation was observed in the case of paddy straw followed by rice husk, mixed substrate, water hyacinth and least in saw dust. The reason being the dependence of the sporophore initiation upon the nature of substrates used as bedding material. Similar reason was stated by Zadrazil (1978). It was found that paddy straw gave the highest first flush followed by water hyacinth. Similar observations were found in the study of Bahram (1989), Jandaik (1989) and Marimutu et.al.(1991). Superiority of the paddy straw as a subsrate was reported by several workers (Pal and Thapa, 1979; Bahram,1989; Jandaik,1989 and Marimuthu et.al., 1991). They also reported a maximum biological efficiency of P.florida grown on paddy straw, which was found similar to the results of the present study. The present study showed high level of protein and minimum level of lipid in the P.florida grown on different substrates. The findings of Randive, 2012 support the findings of the present study.

\section{Conclusion}

The highest yield, highest biological efficiency, maximum protein, carbohydrate and caloric value were recorded in the P.florida grown on paddy straw substrates while the least were seen in the case of saw dust grown P.florida. To conclude, paddy straw among the five substrates used is more suitable for the cultivation of P.florida. Though mushroom cultivation, combating malnutrition and protection of the environment is also possible for the successful sustenance of human life and ecosystem.

\section{References}

[1] Bahram, H., 1989. Mushroom Journal, 9:97-100.

[2] Bano, Z and Srivastav, 1962. Studieson the cultivation of Pleurotus species, Food Science, 11:363-365.

[3] Block, S.S., Tsao, G. and Han, L., 1958. Production of mushrooms from saw dust. Journal of Agricultural and Food Chemistry,6: 923-927.

[4] Dike K. S., Amuneke E. H., and Ogbulie J. N., 2011. J Microbiol. Biotech.Res., 2011, 1(3):1-4.

[5] Folch, J., Lees, M. and Sloane Stanley, G.H., 1957. A simple method for the isolation and purification of total lipids from animal tissues, J. Biol. Chem., 266:497-509.

[6] Hedge, J. E. and Hofreiter, B. T., 1962. In: Carbohydrate Chemistry, 17, Academic Press, New York.

[7] Lowry, O. H., Rosebrough, N. J., Farr, A. L. and Randa, R. J., 1951. J. Biol.Chem.,193:265.

[8] Marimuthu, T., Krishnamoorthy, A. S. and Jayarajan, R., 1991. Glimpses of Mushroom Research in Tamil Nadu Agricultural University, Coimbatore, P.63.

[9] Pal, J. and Thapa, C. D., 1979.Cultivation of Dhingri made easy, Indian Journal of Mushrooms, 5:7-20.

[10] Pani, B. K., and Mohanty, A. K., 1998. Utilization of water hyacinth as an alternative substrate for oyster mushroom cultivation, Crop Res., 15:294.

[11] Shah Z. A, Ashraf M, \& Istiaq M. 2004. Comparative Study on Cultivation and Yield performance of Oyster Mushroom (Pleurotus ostreatus) on Different Substrates (Wheat Straw, Leaves, Saw dust). Pakistan Journal of Nutrition 3(3):158-160 Asian Networks for Scientific Information.

[12] Sharma, A. D., and Jandaik, C. L., 1981, Quality of paddy straw and its effect on spawn run and yield of Pleurotus sajor-caju, Indian Journal of Mushroom, pp. 84-87.

[13] Sonali D. Randive, 2012 Cultivation and study of growth of oyster mushroom on different agricultural wastes substrate and its nutrient analysis: Advances in Applied Science Research,3(4):1938-1949.

[14] Zadrazil, F. and Schneidereit, M., 1972. Die Grudlagen for die Inkultumahme einer bisher nicth kultivierten Pleurotus Art, Der Champion, 12:25-32

[15] Zadrazil, F., 1978. Cultivation of Pleurotus. In the Biology and Cultivation of edible mushrooms, (ed. S.T. and W.A. Hayes), Academic Press, New York, pp. 251-256. 